\title{
A educação como ponto de confluência na obra de Jean-Jacques Rousseau
}

Vilmar Alves Pereira

Professor da Universidade Federal do Rio Grande do Norte

\section{Resumo}

O presente artigo se propõe a discutir o papel da educação em três obras do filósofo e pedagogo Jean Jacques Rousseau: Emílio ou da educação, O contrato social e Emile e Sophie on Os solitários. Partindo de inúmeras leituras e análises criteriosas, é possível identificar uma grande coerência no pensamento de Rousseau, imbuído de aspectos pedagógicos que são desenvolvidos de uma forma processual. A principal tese que defendemos é a de que não existe contradição entre aquilo que Rousseau pensou como educação (do homem natural) e como política (do cidadão), ao contrário, na proposta de Rousseau a educação funciona como pressuposto para a formação moral e política.

Palavras-chave: Educação; Confluência; Rousseau.

\begin{abstract}
This article that aims to discuss the role of education in three works of the philosopher and educator Jean Jacques Rousseau's Emile, or On Education, The Social Contract and Emile and Sophie, or the lonely. Starting from numerous readings and careful analysis, it is possible to identify a great consistency in Rousseau's thought, imbued with pedagogical aspects that are developed in a procedural way. The main thesis we defend is that there is no contradiction between what Rousseau thought such as education (natural man) and a policy (the citizen), in contrast, the proposed Rousseau education works as a precondition for moral and political.
\end{abstract}

Keywords: Education; Confluence; Rousseau.

Filosofia e Educação - ISSN 1984-9605 - Volume 4, Número 2

Outubro de 2012 - Março de 2013 
Primeiros argumentos: situando o Emílio

lguns estudiosos, como é o caso de Oliveira (1977) e Chateau
(1978), já faziam questão de afirmar que a obra de Rousseau
encontra-se quase toda concatenada, ou seja, não podemos ler Emílio, Os solitários, O contrato social a Nova Heloísa e Os primeiros discursos sem perceber a grande tese que é apresentada em sua obra: educar o ser humano para que desenvolva todas as suas potencialidades na república. Nisso consiste a sua tarefa pedagógica:

Hoje em dia trabalhos eminentes (em particular de Burgelin e de Derathé) tornaram obsoleta a interpretação por vezes proposta antigamente, segundo a qual Émile seria à parte da obra. Mas o próprio Rousseau viveu a assinalar a unidade de sua obra (Chateau, 1978, p.172).

Há pensadores, como é o caso de Voltaire, que até afirmam ser Rousseau um autor que propõe uma educação isolada. Contrariando a isso vamos às teses. No Emílio já no seu início considera que: “Tudo está bem quando sai das mãos do autor das coisas, tudo se degenera entre as mãos dos homens" (Rousseau, 1995, p.7); no Contrato Social: "O homem nasce livre e por toda a parte encontra-se a ferros" (Rousseau, 1973, p.28).

Percebemos, nas transcrições, a primeira identidade na obra roussauniana. Para entender isso, devemos ter clara a noção de natureza boa, ou seja, o ponto de partida nas duas obras é o mesmo, como afirma considera essa autora:

Esses dois livros por tratarem de assuntos aparentemente opostos, têm sido considerados pelos intérpretes do autor como inconciliáveis, todavia, quando analisamos não só esses livros como as demais obras de Rousseau, inclusive sua correspondência, verificamos que eles são complementares (Cerizara, 1990, p.24).

Filosofia e Educação - ISSN 1984-9605 - Volume 4, Número 2

Outubro de 2012 - Março de 2013 
No Emílio, Rousseau, partindo da tese transcrita acima procura demonstrar que o sistema educativo proposto pela sociedade da época, cujos métodos tratavam a criança como um adulto, estava errado. Assim, ao invés de educá-la, passava para a criança uma série de vícios, os quais, sem dúvida, emergiam da sociedade da época, que negava a natureza. Diante desse quadro, Rousseau propõe uma educação diferente (descrita no Emílio), que consiste numa análise detalhada de todas as etapas pelas quais uma criança passa na sua vida educativa. Isso justifica o porquê de Emílio ser um aluno imaginário; de fato, pela educação da época, ele poderia ser inconcebível.

A proposição de educação de Rousseau nessa obra ( $O$ Emílio), não segue o viés da sociedade daquele período, mas o da lógica da natureza. Rousseau estruturou o seu livro em cinco partes, seguindo as diferentes fases da vida de Emílio, desde o seu nascimento até a idade de vinte e cinco anos. Nela Rousseau realizou uma das maiores sínteses pedagógica entre o sentimento e a razão a partir de seu aluno Emílio:

Enquanto todos se voltam para as explicações racionais e objetivas marcadas pelo primado da razão, Rousseau revela uma maneira própria de pensar, em que utiliza tanto o coração quanto o intelecto. No Emílio, especificamente, a síntese emoção e razão enfatizada em algumas passagens pelo discurso em primeira pessoa, cria um clima em que, ao escapar do real, através de seus devaneios, ele não só transforma este real, como recria (Cerizara, 1990, p.30)

Nas primeiras páginas do livro I, Rousseau preocupa-se em demonstrar, demoradamente, as diferenças existentes entre o homem natural e o homem civil (ou artificial). Isolando o Emílio da sociedade vigente, Rousseau concebe-o como unidade indivisível; já o homem civil só é concebido a partir da sociedade e é unidade fracionária. Estabelecendo esse

Filosofia e Educação - ISSN 1984-9605 - Volume 4, Número 2

Outubro de 2012 - Março de 2013 
paralelo entre os dois conceitos de homem, Rousseau critica todo o sistema de educação que rotula, que não trata o aluno como indivíduo; critica, em toda a sua obra, o sistema de preceptores da época e, com isso, vai apresentando os seus objetivos e o seu concepção de educação.

O objetivo inicial de Rousseau apresenta-se como algo extremamente complexo: "Nosso verdadeiro estudo é o da condição humana" (Rousseau, 1995, p.14). Mais adiante, nesse mesmo livro, ele faz questão de manifestar que viver é o ofício que ele quer ensinar. Surge-nos a interrogação: viver de que modo? E percebemos que consiste em viver de acordo com a natureza. Nessa altura, Rousseau não está preocupado em fazer grandes explanações; simplesmente se preocupa em sugerir uma nova condição humana, livre de todos os erros que existem na sociedade. Desse modo considera que, "começamos a nos instruir quando começamos a viver" (Rousseau, 1995, p.14). E como em nossa vivência inicial necessitamos do auxílio de alguém, o autor faz uma demorada análise da forma como as amas-de-leite (babás) dão um tratamento errado às crianças desde o nascimento. Ele analisa desde o modo incorreto de pôr as fraldas e faixas no corpo dos bebês até a educação comportamental, como também a educação da linguagem da criança.

Com o intuito de demonstrar os erros que a sociedade comete na fase inicial da educação desse período, Rousseau analisa detalhadamente o fato de as amas-de-leite não educarem a criança para se vestir: elas amarram fortes faixas no corpo dos pequenos, quando, ao contrário, deveriam deixálos livres; desde o nascer, utilizam métodos que, mais tarde, irão influenciar na falta de espontaneidade da criança, um dos quais é o vestuário. Essas primeiras educadoras, segundo Rousseau, deixam a criança imperar pelo choro, ao invés de a distraírem; ensinam-na a decorar palavras cujo significado ela não entende, ao invés de lhe ensinarem palavras práticas e

Filosofia e Educação - ISSN 1984-9605 - Volume 4, Número 2

Outubro de 2012 - Março de 2013 
claras, como era o caso do Emílio. Rousseau entende que o choro representa uma grande arma para as crianças. Quando elas descobrem o seu potencial e os pais se descuidam, ocorre um abalo no processo educativo, no qual a criança é que passa a mandar.

Nesse livro, ainda, Rousseau traça um paralelo entre a criança educada na sociedade civil de sua época e a criança camponesa (lembramos aqui a estrutura da sociedade de classes da França). Em razão de valorizar a natureza, Rousseau dá primazia ao método espontâneo de educação da criança criada no campo. Eis um exemplo em que fica clara essa primazia, referentemente à linguagem do campo:

No campo, tudo é diferente. A camponesa não fica todo o tempo junto ao filho; ele é obrigado a apreender a dizer bem claramente e bem alto o que tem necessidade que ela ouça. Nos campos, as crianças soltas, longe do pai, da mãe e das outras crianças, exercitam-se em se fazer ouvir à distância e a medir a força da voz pelo intervalo que as separa daqueles por quem querem ser ouvidas. Eis como realmente se aprende a pronunciar, e não gaguejando algumas vogais no ouvido de uma governanta atenta (Rousseau, 1995, p.60).

Demonstrada a preferência que Rousseau dá ao método simples e natural do camponês, a vida de Emílio está sempre centrada no livro da natureza. Buscando a preservação e o desenvolvimento da natureza, a nova educação cuida para que a criança não possua inúmeros preceptores, mas somente um, que a acompanhe dos zero aos vinte e cinco anos. Essa é uma norma que será estabelecida para Emílio. Um único professor conhece melhor seu aluno e possibilitar-lhe um melhor acompanhamento; Emílio desenvolverá com espontaneidade todas as fases de sua existência, sem queimar nenhuma delas; Emílio buscará a leitura apenas do livro da natureza.

Filosofia e Educação - ISSN 1984-9605 - Volume 4, Número 2

Outubro de 2012 - Março de 2013 
No livro II, Rousseau continua desenvolvendo seu método, afirmando que ele pressupõe também alguns esforços. Se a criança quer aprender a correr, por exemplo, ela está sujeita a cair, e sua grandeza consiste em saber se levantar por conta própria. Agindo assim, estará aprendendo a gozar o bem-estar da liberdade. No entanto, a sua crítica continua sendo aos que não respeitam esse desenvolvimento espontâneo da criança, tornando sua vida cheia de sacrifícios e privações, sem propor nenhum fim educativo para a sua vida. A proposta de Rousseau é singela: a humanização dos homens como condição fundamental.

Ainda no livro II, Rousseau faz uma forte crítica à educação desenvolvida de zero a doze anos. Segundo ele, apagar esse modo de educação que recebem nessa fase seria a melhor saída, pois a criança não está preparada para assimilar tantos conhecimentos. Também é nessa fase que elas adquirem os maiores vícios. Emílio deve aprender apenas aquilo que lhe é útil?

No livro III, Rousseau acompanha um Emílio em fase de definição de personalidade e de perspectivas futuras. Estamos falando da Idade da Força. Rousseau introduz esse livro discorrendo sobre a fase dos 12 aos 15 anos, com a preocupação básica da educação intelectual e da educação manual, dando primazia à educação manual. Na verdade, na Idade da Força, é preciso reforçar a importância da experiência. Essa preocupação é tão saliente que, questionando-se sobre o que fazer com esse período em que a criança pode mais do que deseja, o autor afirma que deve ser preenchido com trabalhos manuais, com experiências práticas. No entanto, adverte que esse curto período de tempo não pode passar despercebido, pois entende que é um tempo muito valioso e decisivo para vida humana: "É o tempo mais precioso da vida, tempo que só aparece uma vez: muito curto e, por ser tão curto, é importante que seja bem empregado" (Rousseau, 1995, p.202).

Filosofia e Educação - ISSN 1984-9605 - Volume 4, Número 2

Outubro de 2012 - Março de 2013 
Ainda na primeira parte do livro III do Emílio, Rousseau revela que a sua preocupação não é repetir os métodos dos preceptores da época, mas reforçar sua maneira de educar. Por isso, o aluno rousseauniano não tem, nessa fase, muitas leituras nem muitas aulas teóricas; aprende geografia em passeios pelos bosques. O verdadeiro mapa Emílio aprende com a experiência, não simplesmente desenhando e decorando, como fazem os outros alunos.

No que diz respeito à leitura, no livro III do Emílio, Rousseau faz questão de mencionar que seu aluno não lerá muitos livros. No entanto, indica um livro e justifica o porquê dessa indicação: é o livro de Robinson Crusoé como um desafio de aprendizagem voltada para solução de problemas cotidianos.

A preocupação do autor nessa fase centra-se em somente ensinar aquilo que é claro e que pode servir para a vida do educando. Segundo ele, ensinamos demasiadamente expressões cujo verdadeiro significado as crianças não compreendem no momento. Isso justifica a recomendação do livro referido, que, em seu enredo, apresenta a narrativa de uma história que contribui para uma análise prática. Aqui emerge um outro conceito do livro III: o conceito de utilidade. Segundo Rousseau, o adulto deve saber com clareza aquilo que uma criança ainda não é capaz de entender. Então, quando uma criança nos dirige uma pergunta, devemos, com o intuito de seu melhor aprendizado, responder-lhe com outra pergunta: "Em que isso que me perguntas é útil de saber?” (Rousseau, 1995, p.224).

A segunda parte do livro III detém-se em mais uma das preocupações do autor, que consiste no emprego da força desse adolescente. Para isso, sugere a necessidade de um ofício para seu aluno: é chegada a hora de Emílio trabalhar. O intuito do mestre é que Emílio, nessa fase de sua vida e de seu aprendizado, escolha uma profissão honesta e que tenha

Filosofia e Educação - ISSN 1984-9605 - Volume 4, Número 2

Outubro de 2012 - Março de 2013 
utilidade. Transparece nessa parte um dos grandes ideais da educação rousseauniana: a defesa de uma vida digna, com uma educação para o trabalho que enaltece a condição humana. Profissionalmente, Emílio vai ser marceneiro, um trabalho modesto que deve ser acompanhado pelo mestre diariamente. Assim, o aluno de Rousseau desenvolverá as suas atividades físicas e empregará as suas forças em algo extremamente útil. Emílio é extremamente temperante, paciente, firme, trabalhador e cheio de coragem; as primeiras manifestações do julgar estão nele começando a emergir. É um aluno feliz porque a natureza lhe permitiu viver com felicidade; não tem erros, nem vícios. Tem poucos conhecimentos, mas os que tem são realmente seus.

Percebemos, no livro III, que o autor enfatiza a necessidade do conhecimento prático e das coisas que realmente sejam úteis para a vida. Apreendida a profisssão, Emílio está com seus 15 anos, quando, ainda, sabe pouco sobre os homens. Faz-se necessária, agora, a presença da moralidade e da racionalidade para que conheça melhor os homens. Essa etapa será o tema do IV livro do Emílio.

Nesse livro os principais conceitos trabalhados são: a educação moral do Emílio, a educação religiosa, a educação sexual e a educação racional, que emerge junto com a educação moral. A idade das paixões e a idade da razão caracterizam um novo nascimento no homem: "Nascemos, por assim dizer, duas vezes: uma para existir, outra para viver; uma para a espécie, outra para o sexo" (Rousseau, 1995, p.176). Rousseau está preocupado em manifestar mais uma necessidade humana: a de que o homem evolui, porém sua evolução deve ser acompanhada. Ele considera essa idade como um momento de crise, curto, mas muito importante para a vida vindoura; é um período, que sem dúvida, merece uma atenção especial. $\mathrm{O}$ autor considera isso como o segundo nascimento; é a hora em que a

Filosofia e Educação - ISSN 1984-9605 - Volume 4, Número 2

Outubro de 2012 - Março de 2013 
realidade se apresenta como realmente é. Emílio está começando a conviver com os homens. O mestre está consciente de todas as armadilhas em que seu aluno poderá cair, no entanto está seguro e convicto de que, em sua educação, desenvolveu uma das faculdades mais importantes de seu aluno: a capacidade de julgar ou a razão. Emílio não será um mero racionalista; ao contrário, saberá distinguir as paixões verdadeiras das medíocres. Isso porque é impossível negá-las; para Rousseau, elas fazem parte da natureza humana: "Se Deus dissesse ao homem para destruir as paixões que lhe dá, Deus quereria e não quereria; estaria se contradizendo" Rousseau, 1995, p. 273).

Rousseau entende que as paixões naturais são limitadas. Discorrendo sobre as paixões naturais, ele evidencia uma que considera como a primeira, a fonte de todas as paixões: o amor de si. Mas em que consiste o amor de si? “O amor de si é sempre bom e sempre conforme a ordem estando cada qual encarregado de sua própria conservação, o primeiro e mais importante de todos os cuidados é e deve ser zelar por ela continuamente.” (Rousseau, 1995, p.274)

Rousseau identifica uma paixão benigna, uma necessidade natural de o homem se conservar. O amor de si não é egoísta como o amor-próprio, é ele que começa a despertar o homem para a consciência moral. Dessa forma, para Rousseau, o quanto mais se afastar as crianças dos desvios do amor-próprio, mais estaremos contribuindo para o desenvolvimento da natureza. Ainda na idade da razão e das paixões, surge a necessidade de uma companheira. Aqui começa para Rousseau a existência de um estado crítico. Por precisar de uma companheira, o homem não se sente isolado, seu coração já não está mais sozinho; porém, precisa de algumas normas mínimas para a relação com outrem. Eis a necessidade da moral.

Filosofia e Educação - ISSN 1984-9605 - Volume 4, Número 2

Outubro de 2012 - Março de 2013 
Emílio está num mundo onde corre, frequentemente, perigo. Até então, havia olhado somente para si mesmo; a partir de agora, começará a olhar os outros seres e passará, então, a compará-los. Essa comparação possibilitará que não aceite as paixões medíocres tão precocemente. Nessa fase, a maior preocupação de Rousseau está em manter seu aluno forte e autônomo para enfrentar todos os problemas que emergem constantemente. Quando Emílio compara suas ações com as dos demais, percebe a diferença que há entre o amor de si (gosto e preservação de si mesmo) e o amorpróprio, que é um amor movido pela paixão da propriedade, da força, da luta pelos interesses que não tendem para o bem comum. Para Rousseau, no estado de natureza, há uma igualdade de fato, o mesmo não ocorrendo no estado civil. Isso justifica a necessidade de leis morais para que não se repita a dependência de uns em relação aos outros. Preocupado com um melhor conhecimento da sociedade e, consequentemente, com um melhor conhecimento do homem, para que seu aluno seja mais bem esclarecido. Um dos conselhos que passa a Emílio é que ele observe as ações humanas, pois é pelas ações que podemos conhecer melhor o homem. Emílio deve, assim, julgar essas ações. Nesse julgamento, emergirão aspectos que dizem respeito à justiça e às injustiças nas ações humanas. É a questão da ética e da religião que está se apresentando.

A educação de Emílio não está acabada; é preciso conhecer a natureza e a base do sentimento religioso. Sobre a profissão de fé do vigário saboiano, Rousseau utiliza no livro IV o pretexto para criticar o sistema religioso da época e propor um modelo de crença religiosa para a educação de Emílio que seguisse a lógica do cultivo e da preservação daquela natureza boa que ele tanto defende (A religião natural). Nesse livro, buscando as provas que lhe dessem maior certeza sobre a existência de Deus, ele consegue apontar para um viés diferente daquele que seguia

Filosofia e Educação - ISSN 1984-9605 - Volume 4, Número 2

Outubro de 2012 - Março de 2013 
Voltaire, ou seja, afirma que a existência de Deus pode ser provada pela percepção de um impulso interior que move o homem: a consciência. É a consciência de que há uma vontade superior que move o universo e uma inteligência superior que move a matéria segundo certas leis. Disso resulta que a existência de Deus é provada pela harmonia do mundo. Temos, entretanto, de estar atentos ao mal que é oriundo das paixões que depravam a consciência. $\mathrm{O}$ itinerário que Rousseau segue em sua argumentação é o seguinte:

Da harmonia do universo Rousseau chega a uma inteligência suprema e uma bondade suprema, isto, é, Deus. Ele se anula diante da majestade do ser eterno. Cada vez que quer conhecer melhor este Deus, choca-se com explicações contraditórias que não se pode resolver; assim pensa que é preciso renunciar conhecer Deus de uma maneira mais precisa. É preciso limitar-se ao culto do coração, escutar sua voz, ser tolerante, praticar a virtude. O culto do coração pode tornar o homem feliz (Motta, apud, Suliani, 1979, p. 99).

Aqui ele aproveita para fazer uma crítica aos métodos religiosos da época como também às abstrações da filosofia (metafísica) que, segundo ele, ao invés de contribuir para a religião, apenas cria confusões. Disso resultaria, mais tarde, que a Igreja Católica condenaria o seu livro Emílio, mandando-o queimar.

A maneira como Rousseau trata a questão de religião deixa cada vez mais evidente a identificação com seus postulados morais: a religião deve conduzir o homem a uma maior conscientização dos seus atos em busca da felicidade: "Deus nos fez de tal maneira que se usamos a nossa liberdade para viver como justos e manter a fé em harmonia com a nossa própria natureza seremos felizes" (Rousseau, 1995, p.328).

$\mathrm{Na}$ verdade, a grande questão da moral e da religião, em Rousseau, é uma questão presente em todos os jusnaturalistas como também nos 
filósofos do século posterior. O que vemos é que, para legitimar qualquer aspecto da moralidade, não se podem dispensar as práticas e crenças religiosas da época. A religião funciona como um elemento que serve à objetivação das ideias morais.

Estamos reafirmando que a crítica de Rousseau não é um desprezo à totalidade religiosa, mas à demonstração dos interesses humanos imersos no processo de sujeição de uma grande maioria que, pela autoridade de Deus, obedece a vontades alheias. É o que o primeiro Estado francês, aliado à Igreja, mantinha como prática. Tanto o é que Rousseau assume alguns aspectos que considera importantes na religião, como, por exemplo, os deveres da moralidade.

Finalmente, para o autor, não é no livro dos homens (a Bíblia), no que declara o vigário, mas no livro da natureza - que está aberto e acessível a todos indistintamente - que aprendemos "a servir e a render culto ao divino autor." (Rousseau, 1995, p.473).

Emílio já possui a capacidade de julgar, e isso se constitui também na elaboração de sua moral. Possui, ainda, os mandamentos da nova religião, que não está embasada em inúmeros sacrifícios, mas numa verdadeira aposta no desenvolvimento da natureza humana. Nessa fase, já conhece um pouco mais sobre os homens; ainda não possui namorada, é paciente e reflexivo. No entanto, está próximo dos seus vinte anos, a idade ideal para escolher uma companheira e inserir-se, de vez, na sociedade.

No livro V, ao nos aproximarmos da sua Idade da Sabedoria, podemos inferir que já foram passados a Emílio os conceitos essenciais para o bom desenvolvimento de uma vida social. O aluno já tem uma profissão, já possui a capacidade de julgar e possui também elementos morais e religiosos. Como Rousseau preocupa-se com a preservação daquilo que é

Filosofia e Educação - ISSN 1984-9605 - Volume 4, Número 2

Outubro de 2012 - Março de 2013 
natural, o casamento se apresenta como algo que continua desenvolvendo a lógica da natureza:

Eis-nos chegado ao último ato da sua juventude, mas ainda não estamos no desfecho. Não é bom que o homem esteja só, e Emílio é homem; prometemos-lhe uma companheira, é preciso dar-lha. Essa companheira é Sofia (Rousseau, 1995, p.491).

No livro V do Emílio, Rousseau passa o tempo todo demonstrando a identidade de Sofia e escreve sobre a importância da mulher no casamento; posteriormente, conta como foi que Emílio a encontrou. Finalmente, com o casamento, está concluída a missão do mestre. E é mediante as experiências que o aluno adquiriu com seu mestre que ele almeja ter um filho e educá-lo da maneira como foi educado por seu preceptor.

Para Rousseau, Emílio já conhecia Sofia antes mesmo de ter convivido com ela. E justifica sua afirmativa mediante a compreensão de que, em Emílio, havia elementos que o identificavam com sua companheira. Sabe-se, no entanto, que uma mulher com essas características é uma mulher rara. Sofia será filha de camponeses. Cheia de talentos naturais, como já evidenciamos, é ela que Emílio vai namorar e com ela, posteriormente, vai se casar.

Uma marca essencial de cunho formativo é a presença constante de Rousseau na vida de seu aluno, atitude que perpassa toda a sua obra. Até mesmo no livro $\mathrm{V}$, ele marca presença como conselheiro do romance de Emílio e Sofia. Pode aqui ser levantado um questionamento sobre o conceito de autonomia, ou seja: por que deixar Emílio prosseguir sozinho somente aos vinte e cinco anos? Rousseau entende que essa é a fase em que o aluno terá todas as condições para desenvolver suas potencialidades no meio social. Vemos, então, que a educação rousseauniana tende à sua máxima expressão na sociedade.

Filosofia e Educação - ISSN 1984-9605 - Volume 4, Número 2

Outubro de 2012 - Março de 2013 
Alguns conceitos presentes no Emílio precisam ser retomados, entre eles: o conceito de estado de natureza e o conceito de moral. Ambos se encontram vinculados, aliás, como já afirmamos, o conceito de estado de natureza está presente em toda a sua obra e constitui "um instrumento básico do esforço racional de uma construção política-pedagógica" (Oliveira, 1977, p.37). Buscando melhor caracterizá-lo, encontramos, em relação ao estado de natureza vemos que em Rousseau esse estado existe de fato:

Assim entendido o estado de natureza é muito mais uma hipótese de trabalho do que uma realidade propriamente dita. É do estado de natureza que deve começar o estudo; e ele progredirá por esta análise ideológica que vai do simples ao composto, do primitivo ao atual (Oliveira, 1977, p.38).

Se Rousseau desejasse que o homem permanecesse no estado de natureza, certamente seu aluno Emílio não seria uma construção fictícia, mas tomaria como estudo um ser real. Mas se esse estado é pensado como bom, por que o homem não deve permanecer nele? Com relação a esse aspecto, Rousseau deixa bem claro que a bondade existente no estado de natureza é uma bondade pura, ingênua e espontânea. Nele, o homem, com intuito de se preservar, não faz mal a ninguém, até porque não existe nenhuma lei que possa julgar as suas ações como boas ou más. No entanto, se não existem leis, não existe moral; logo, é um estado mais instintivo que racional que impulsiona o homem a se conservar. Existe nele uma espécie de inocência animal.

Desse modo vimos na análise de toda a obra que Emílio possui a bondade natural. Então, para que educá-lo? Sem dúvida, é para elevar a sua natureza além da sua animalidade, numa esfera onde existam leis. Assim o projeto de Rousseau é um projeto aberto, que procura desenvolver o ser

Filosofia e Educação - ISSN 1984-9605 - Volume 4, Número 2

Outubro de 2012 - Março de 2013 
humano racionalmente, preservando a sua bondade e inserindo nela a moral. Os primeiros conceitos de moral começam a ser desenvolvidos no livro IV do Emílio; no entanto, ganham forma e expressão somente na obra $O$ contrato social, especificamente na ideia de república proposta por Rousseau, onde, segundo ele, as leis possibilitarão que as ações humanas sejam realmente morais e livres.

A natureza, na república, é consciente e boa, pois tem as leis do contrato como escudo, do que resulta que a proposta pedagógica rousseauniana está imbuída de uma preocupação de educar para o social; nela, a moralidade não pode ser desenvolvida isolando o homem do convívio social. No Emílio, quando Rousseau está desenvolvendo em seu aluno os primeiros conceitos de moral, ele o leva frequentemente a jantares, nos quais, em convívio com os outros, seu aluno começa a desenvolver a sua moralidade pela capacidade de julgar.

A moralidade é uma causa necessária para o desenvolvimento e preservação da natureza boa do ser humano. Na forma como Rousseau constrói sua teoria, a ideia de lei aparece vinculada com a ideia de desenvolvimento. No Emílio, o aluno é preparado para a inserção social. Como vimos, em todas as fases do desenvolvimento sadio e espontâneo, o aluno de Rousseau possui indicativos que lhe possibilitam uma educação para uma melhor convivência futura, diferenciada daquela em que ele se encontrava inserido - sociedade civil.

\section{Contextualizando Os solitários}

Na obra Os solitários, há um conflito muito grande entre a preservação da natureza de Emílio e Sofia e a sociedade na qual vão conviver, a sociedade civil; nela, para Rousseau, existe a imoralidade e o vício; no entanto, isso não os afasta da sociedade. Nesse sentido, a obra Os solitários é de grande 
contribuição, pois, com base na sua análise, podem ser demonstradas as contradições entre o projeto de Rousseau e a sociedade civil. Após apresentá-la, buscaremos no Contrato social a possibilidade de realização do ser humano na república, pela possibilidade de a educação seguir o princípio da vontade geral. Assim, buscaremos demonstrar pela educação a possibilidade de unidade entre homem natural, homem social e cidadão da república.

A apresentação da obra Os solitários dentro da dessa tese de que a educação é o grande ponto de confluências do pensamento de Rousseau tem bem claro o seguinte objetivo: demonstrar que o projeto pedagógico de Rousseau não foi pensado para a sociedade civil. Isso pressupõe, de antemão, que a concepção de Rousseau de sociedade civil parte da ideia de negação da negação que consiste em identificar na sociedade de seu tempo inúmeras contradições que não tendiam para o desenvolvimento da natureza humana, ao contrário, a corrompiam. Esse dado levou Rousseau, diferentemente de Locke e Hobbes, a construir inúmeros artifícios e observações como críticas da sociedade civil, entendendo que, se ela nega o desenvolvimento da natureza humana, então deve ser negada.

$\mathrm{Na}$ obra Os solitários, transparecem com muita nitidez as características da sociedade criticada por Rousseau. Na proposta de Rousseau, a mentira é algo intolerável; ela faz parte da sociedade que Rousseau considera artificial e do mundo onde Emílio e Sofia vão ser inseridos. Como decorrência da mentira vem a traição. No livro $O s$ solitários, a traição faz parte dos desejos do homem que quer enganar a sua natureza. A sociedade civil, para Rousseau, age de forma imoral por desconsiderar muitas vezes o interesse comum e se constitui num meio onde o homem movido pelo impulso do amor-próprio pode trair constantemente o seu semelhante.

Filosofia e Educação - ISSN 1984-9605 - Volume 4, Número 2

Outubro de 2012 - Março de 2013 
Rousseau denuncia o interesse pessoal que rege a sociedade civil. Foi o interesse pessoal de Sofia que substituiu o verdadeiro amor de Emílio. Esse amor é egoísta, é o amor-próprio que move o ser humano. Disso resulta que a cidade é o ambiente no qual é possível ser identificados com maior nitidez os anseios egoístas que segundo Rousseau, impulsionam a sociedade civil; o meio urbano, não desenvolve o homem por inteiro. É nesse meio que Emílio e Sofia irão viver e estarão expostos às maiores provações. Esse ambiente é perversivo para Rousseau.

No livro Os Solitários, o sentimento de solidão permeia toda a obra, demonstrando como a natureza boa não está preparada para esse tipo de convivência social. A cidade é mais artificial de que o campo. Na cidade, a ganância está motivada pela ideia de propriedade (fruto do contexto industrial que estava emergindo). Há também um maior relativismo ético e imoralidade, de modo que Emílio e Sophia, longe de seu mestre, sentem-se despreparados para viver no meio urbano. Os costumes e hábitos adquiridos pela sua educação não se adaptam com o ambiente urbano. Rousseau não concorda com algumas manifestações desse meio:

A indignação de Rousseau (ele próprio homem natural) contra a sociedade (criação histórica) é a expressão patética desse conflito. Ele toma a palavra para dizer não à antinatureza. (Starobinski, 1981, p.36).

A sociedade civil, para Rousseau, é contraditória, dividindo o homem ao invés de integrá-lo. Ela desperta o orgulho e as ambições, o medo e a insegurança, a traição e a disputa, o desejo e a ganância. Em toda a sua obra e no Os solitários há um debate envolvendo a questão da moralidade e o problema econômico. O homem, motivado pela posse torna-se imoral por seguir os impulsos do amor-próprio.

Filosofia e Educação - ISSN 1984-9605 - Volume 4, Número 2

Outubro de 2012 - Março de 2013 
Temos de ler Os solitários atentos para esse contexto, com o que será possível entender a frustração de Emílio em seu grande esforço para conviver na sociedade civil. Nessa obra, Emílio sente as mesmas desconfianças que Rousseau sentia em relação à sociedade civil. $\mathrm{O}$ bom homem de seu tempo sente-se só por não possuir os mesmos interesses. Parece contraditório sentir-se solitário na sociedade, no entanto é isso que ocorre quando não existe conformidade entre o real (sociedade civil) e um novo ideal (uma educação que preserva a natureza boa), aquela educação de iguais da república. Entendemos que o propósito de Rousseau não é extinguir a sociedade, a ciência e as artes; ao contrário, denunciando seus equívocos, ele pretende apontar para uma nova sociedade (república) e uma nova forma da ciência contribuir para o desenvolvimento da natureza do homem. Eis o espaço em que Emílio e Sofia se encontram solitários: na sociedade civil.

\section{Emile e Sophie ou Os solitários}

Quando pensávamos que já tínhamos chegado ao ápice da educação de Emílio; quando seu mestre lhe havia dado uma companheira; quando a felicidade aparente passara a ser uma constante na vida do aluno de Rousseau, surge-nos uma grande questão: como será a vida de Emílio e Sofia longe da proteção de seu mestre? Mencionamos anteriormente que o propósito da educação em Rousseau tende a um fim social: em que sociedade se objetivarão, de fato, os princípios dessa educação? Existe alguma fonte documental que demonstre a continuidade desse processo pedagógico?

Defenderemos aqui a seguinte ideia: a educação de Emílio entra em conflito, com todos os seus princípios quando Emílio passa a viver na sociedade civil. A obra que estudamos minunciosamente constitui-se na 
escrita em forma de cartas, organizada em 1762; é um texto breve, dividido em duas cartas. É mais uma obra hipotética e fictícia como Emílio.

Uma das primeiras novidades da obra Os Solitários é que Emílio, com um tom de muita tristeza, narra a continuidade de sua experiência, vivendo agora num outro universo. A maioria dos comentadores de Rousseau não chega sequer a mencionar essa obra, o que, talvez, se justifique por dois fatos: primeiro, o desconhecimento da obra, pois o próprio Rousseau não chegou a completá-la; segundo, por que alguns debatedores de Rousseau não fazem uma leitura de um Rousseau político, preferindo ficar com uma visão de um Rousseau romântico e, como romântico, ele não iria pôr à prova da dura realidade o seu aluno e sua companheira. Rousseau, contudo, não é ingênuo e escreve Os solitários justamente para demonstrar que seu aluno não foi educado para "voltar a andar sobre quatro patas", como ironizava Voltaire; seu aluno deverá passar pelas mais duras provações da sociedade civil.

Utilizando a voz de Emílio, imerso no mundo social, Rousseau denuncia os métodos selvagens pelos quais as pessoas eram postas à prova na época. Alguns autores deduziram o pressuposto hipotético de um possível final feliz entre Emílio e Sofia, no entanto não é o que ocorre no enredo da obra como vemos no lamento de Emílio:

Eu era livre, era feliz, oh, mestre! Você fizera em mim um coração apropriado para desfrutar da felicidade, e me dera Sophie. Às delícias do amor, às efusões da amizade, uma família incipiente acrescentava os encantos do afeto paterno: tudo me prenunciava uma vida agradável, tudo me prometia uma doce velhice e uma morte tranquila nos braços de meus filhos. Ah! O que foi feito desse tempo feliz de deleite e esperança em que o futuro embelezava o presente, em que meu coração embriagado de alegria sorvia a cada dia um século de felicidade? Tudo se evaporou como um sonho; ainda jovem perdi tudo, mulher, filhos, amigos, tudo enfim, até o contato com meus semelhantes (Rousseau, 1994, p.13).

Filosofia e Educação - ISSN 1984-9605 - Volume 4, Número 2

Outubro de 2012 - Março de 2013 
Com essa citação, fizemos questão de demonstrar o teor da obra. Vemos um aluno vivendo um presente demasiado confuso e, ao mesmo tempo, trazendo à tona inúmeras reminiscências de um passado que era promissor. Na primeira carta já de início, o aluno faz questão de demonstrar tudo o que perdeu: a infância boa e feliz, a capacidade de julgar, como aprendera na Idade da Razão. Aqui, podemos lançar um olhar atento ao projeto pedagógico rousseauniano e perguntar: o que teria ocorrido de tão forte que fez um jovem com a melhor educação de sua época, com um dos melhores preceptores, constatar, com profunda tristeza, as perdas ocorridas na sociedade civil?

Como tentativa de resposta, Emílio continua discorrendo sobre uma das questões que consideramos ter sido um dos fatores de tamanha decepção: como trabalhar as paixões. Como tentativa de se remeter a essa esfera, ele formula a seguinte questão: "Mas que ser sensível consegue viver sempre sem paixões? Não é um homem; é um bruto, ou é um Deus" (Rousseau, 1994, p.23). Essa expressão de Emílio remete-nos, no mínimo, a duas características básicas sobre o modo como Rousseau concebia o ser humano e, consequentemente, a educação. Retornando ao livro I do Emílio, poderemos perceber uma das suas características fundamentais: a vocação pelo ser humano. Como alguém que busca estar sempre invocando o ser humano, seria impossível que ele negasse a dimensão das paixões, pois elas são próprias daquela natureza boa que tanto enfatiza. Na sua educação, transparece essa vontade de preservar o homem como ele realmente é, e não um homem como deveria ser, segundo os princípios da educação essencialista, que mantinha grande influência em sua época.

Mas que fatores e de que forma continua se desenvolvendo o enredo da primeira carta sobre a experiência de Emílio na sociedade civil para que

Filosofia e Educação - ISSN 1984-9605 - Volume 4, Número 2

Outubro de 2012 - Março de 2013 
gerasse tantas mágoas e frustrações? Um primeiro aspecto que o ex-aluno evidencia é o distanciamento do mestre em relação ao casal. Nesse sentido é importante lembrarmos como ocorre essa provação dos princípios nos quais os "pupilos” foram educados: “(...) mas ela nos lembra que os dois heróis vivem numa sociedade pervertida, e estão sempre ameaçados por essa perversão. Toda a educação continua um risco" (Chateau, 1978,p.180). No próprio nome Os solitários, está intrínseca a dura provação do projeto rousseauniano. Segundo Emílio, vários episódios ocorreram após a ausência de seu mestre, os quais o marcaram de tal maneira que ele chegou a constatar que "o céu logo cessou de abençoar uma casa onde você não mais morava" (Rousseau, 1994, p. 31).

Sophie perde os seus pais, com o que jamais será a mesma; muda completamente o seu semblante, que antes era alegre, o que provoca um tamanho desencanto pela vida que Emílio sente grandes dificuldades de trabalhar. Eis que aparece um elemento novo no enredo. Como tentativa de fuga daqueles problemas, eles resolvem vender tudo e ir para a cidade. A fuga para cidade significa uma ruptura inicial com os costumes da vida camponesa. $\mathrm{O}$ ambiente camponês, segundo Rousseau, condizia mais com o método da natureza. Fugir significa não querer encarar os problemas normais que a natureza também possui como apontamos no livro I do Emílio. A mudança de Emílio e Sophie desperta naquele inúmeras reminiscências de tudo aquilo que viu e ouviu sobre o homem da cidade na sociedade civil.

Segundo o enredo, Emílio estava com razão ao desconfiar da cidade, pois seus pressentimentos iriam se tornar verazes. A sequência irá demonstrar um esfriamento no relacionamento de ambos; aos poucos, o amor cede espaço para uma amizade; o desgosto e as dúvidas crescem a cada dia; as próprias amizades que eles mantém com outros casais são

Filosofia e Educação - ISSN 1984-9605 - Volume 4, Número 2

Outubro de 2012 - Março de 2013 
falsas, cujo estilo da vida amorosa era algo anormal. Emílio e Sofia tem um filho, o qual Emílio muito ama, no entanto, o que mais lhe causa aborrecimentos é o fato de, cada vez mais, desconhecer a sua própria esposa. Eles vivem de aparências; seu relacionamento tem se descaracterizado; Sofia já não demonstra mais possuir desejo por Emílio: "Já não éramos um, éramos dois: o tom do mundo nos dividira e nossos corações não mais se aproximavam” (Rousseau, 1994, p.31).

Emílio narra que, certa noite, estando os dois sós, surgiu um momento propício para troca de carinhos, mas, quando pensara que havia vencido a longa batalha, foi interrompido dessa forma: "Pare Emile, ela me disse, e saiba que não sou mais nada para você. Um outro maculou sua cama, estou grávida, nunca mais em minha vida você irá me tocar (Rousseau, 1994, p.63).

A partir daí, em tom melancólico, narra todas as dificuldades advindas da separação. Sofre muito e foge da cidade. O enredo é longo mas o que fica reforçado é que a sociedade civil não é o meio para a concretização da proposta pedagógica de Rousseau. Na obra Os solitários isso fica bem saliente, pois vemos um Emílio perdido, amargurado, lamentador, traído e muito só. Disso podemos tirar algumas inferências, como: o homem educado para viver e preservar a natureza boa entra em conflito com a sociedade vigente por encontrar nela o oposto de sua formação. As características do aluno de Rousseau são o lamento contra toda uma sociedade que desconsidera o respeito pelo ser humano. Emílio vive essa provação, mas não está totalmente despreparado. Foi preparado, acima de tudo, para ser homem, e ele o é. No entanto, há grande diferença entre o ser homem de Emílio e o ser homem comum da época. Em toda a obra, transparece também o lamento de Rousseau para com a sociedade. Contudo, seu aluno teve boas lições e, quando foi colocado em prova, não o

Filosofia e Educação - ISSN 1984-9605 - Volume 4, Número 2

Outubro de 2012 - Março de 2013 
decepcionou. A decepção de Rousseau não está, portanto, na educação de Emílio, mas na sociedade em que ele viveu. Então, se o projeto de Rousseau não tem afinidades com o da sociedade civil, qual é a possibilidade de uma educação que tenha como indicativo uma nova sociedade para o aluno de Rousseau?

Pensamos que essa possibilidade existe quando nos voltamos ao conceito de vontade geral, presente na obra $O$ contrato social de Rousseau, a qual apresenta os fundamentos e as possibilidades para uma educação mais democrática, para homens democráticos.

\section{Aproximações com o Contrato social}

Em algumas frases em $O$ Emílio é possível identificar o caráter de univocidade das duas obras em estudo, e que reforçam a ideia de que a educação em Rousseau tem um indicativo social é a ideia da república perfeita:

Se as leis das nações, pudessem ter como as da natureza, uma inflexibilidade que nunca alguma força humana pudesse vencer, a dependência dos homens voltaria então a ser das coisas; reunir-seiam na república todas as vantagens do estado natural e do estado civil; juntar-se-ia a liberdade que mantém o homem sem vícios a moralidade que o educa para a virtude" (Rousseau, 1995, p.78).

Viver de forma natural na sociedade torna-se um grande desafio e requer, no mínimo, a concepção de uma sociedade diferente. Eis aqui a continuação do trabalho de Rousseau e de nosso estudo: a sociedade ou república proposta pelo $O$ contrato social. As proposições defendidas por Rousseau em suas obras demonstram a riqueza e a vastidão de suas ideias. Se ele não é tão sistemático na exposição de suas ideias no romance $O$ Emílio ou da educação, assume, agora, em $O$ contrato social, clareza, lógica 
e retidão de pensamento em sua explanação. As ideias centrais que orientam obra são: no livro I, natureza e convenção; no livro II, soberania e legislação; no livro III, uma análise do governo de modo singular e, finalmente, no livro IV, uma proposição religiosa que muitas vezes se identifica com a moral.

Em $O$ contrato social, Rousseau, partindo da ideia de propor uma república, toma "os homens como são e as leis como podem ser" (Rousseau 1973, p. 27), preocupado que está em verificar, de fato, a realidade socialhumana e os seus vínculos com as legislações vigentes. Nela, além de o autor tecer uma forte crítica social, detém-se em propor um novo modelo social. Para tanto, investiga cuidadosamente a questão da liberdade natural para o condicionamento social, o que reforça a ideia de que o $O$ contrato social foi premeditado quando ainda Rousseau escrevia Emílio e que a proposta de educar Emílio se justificar-se-ía para inseri-lo numa sociedade diferente - a república.

No segundo livro do $O$ contrato social, a legislação, o autor está preocupado em saber como promulgar leis que tendam para a justiça e a igualdade para todos, sem distinção, e que estejam adequadamente interessadas na preservação e no bem-estar geral? Como resposta a essa questão, cada membro do Estado deve colocar os interesses comuns de que compartilha com todos acima dos seus próprios interesses. Isso provocará uma mudança do indivíduo (parte) em nome de um todo maior do qual o membro, de certa maneira, recebe a sua vida e o seu ser. Nisso consiste o exercício da vontade geral.

Surge aqui uma dúvida: quem deverá ou poderá estabelecer leis retas que tendam somente para a vontade geral? O autor afirma que é o legislador. Mas quem é o legislador?

Filosofia e Educação - ISSN 1984-9605 - Volume 4, Número 2

Outubro de 2012 - Março de 2013 
Uma inteligência superior, que visse todas as paixões dos homens e não participasse de nenhuma delas, que não tivesse nenhuma relação com a nossa natureza e a conhecesse a fundo; cuja felicidade fosse independente de nós, que finalmente almejando uma glória distante, pudesse trabalhar num século e fruí-la em outro (Rousseau 1973, p.27).

A leitura do Contrato nos permite inferir que em Rousseau, não existe contradição entre a educação do homem natural e a educação do cidadão. Mesmo que Emílio tenha experimentado a dura realidade da sociedade civil, deve encontrar na república o grande espaço para a sua realização, de acordo com o princípio da vontade geral.

Tanto no Emílio, quanto em $O$ contrato social podemos perceber que a educação não ocorre isoladamente; ela sempre tem um indicativo. É política porque faz uma leitura geral do método tradicional, fechado, que, ao invés de propor o desenvolvimento da vida humana, funcionava como um obstáculo, pelas suas práticas essencialistas que não valorizavam a espontaneidade do aluno. Desse modo, $O$ contrato social propõe uma sociedade onde o vício não é uma constante. Mesmo percebendo na história a existência do vício, o autor indica um viés que não levará a ele: o viés da vontade geral.

A predominância da vontade geral aponta não só para uma sociedade sem desigualdades, como para um ensino que seguirá a lógica da natureza, que se preserva tanto no Emílio como em $O$ contrato social. Essa natureza continua no Contrato, indicando para a liberdade do ser humano, o que, aparentemente, parece contraditório, mas que ocorre na entrega das vontades particulares para a lei que emana da vontade geral.

O fim da pedagogia rousseauniana é a inserção social. Disso resulta que a obra Emílio ou da educação terá maior sentido se for entendida como a demonstração dos aspectos fundamentais para o desenvolvimento da natureza humana. Essa natureza alcançará o ponto culminante na sociedade

Filosofia e Educação - ISSN 1984-9605 - Volume 4, Número 2

Outubro de 2012 - Março de 2013 
proposta pelo contrato social. É questão da natureza e liberdade rousseauniana, ou seja, a natureza só se desenvolverá pela liberdade, e a verdadeira liberdade só poderá ocorrer na república, onde é a moralidade que determina as ações humanas.

A educação, em Rousseau, não almeja educar um homem para viver na selva, mas para viver em sociedade. Essa sociedade, sem dúvida, como vimos, é bem diferente da sociedade francesa na qual Rousseau viveu e a qual negou: é a república de Rousseau. É um ideal de república que propõe mudanças radicais pelo contrato para toda a Europa e, sobretudo, para a França.

Podemos perceber que o conceito de vontade geral é a possibilidade de universalização do projeto rousseauniano, tendo viabilidade para toda e qualquer esfera que trate de relações humanas. Visar ao bem comum na escola é não desejar e competição desenfreada motivada pela lógica do mercado. Dessa forma, é impossível entender separadamente a proposta político-pedagógica de Rousseau.

Se a educação só existe quando tende ao social, ou seja, ninguém educa ninguém para viver só, é no conceito de vontade geral de Rousseau que ela encontra a possibilidade de objetivação das suas finalidades: educar para o bem comum. Nesse contexto, educar para a cidadania é seguir o princípio da vontade geral. Assim, afirmamos que vontade geral e educação são elementos que se apresentam interligados, pois ambos visam à realização do ser humano na esfera coletiva.

\section{Considerações}

Em Rousseau, os aspectos pedagógicos não podem ser entendidos separadamente dos contextos político, filosófico religioso e moral. Como 
vimos, existem inúmeras passagens que demonstram essa forma unívoca de Rousseau propor sua educação:

A proposta educacional do Emílio, ou da Educação, longe de afastar o homem da sociedade, é um elemento de uma conotação moral tamanha, no sentido de assegurar ao homem possibilidades concretas de um verdadeiro exercício de cidadania (Oliveira, 1977, p.92).

Vimos, em toda a nossa análise, que não é possível alcançar essa verdadeira cidadania na sociedade civil. A experiência do Os solitários demonstra os contrastes entre a proposta rousseauniana e a sociedade civil. Disso presumimos que a república foi premeditada para a objetivação do exercício da verdadeira liberdade, regida pela vontade geral. Assim, as obras não são contraditórias; pelo contrário, complementam-se.

Portanto, se no Emílio ou da Educação, a educação for analisada em sentido prático, considerando-se a sociedade de fato é impossível uma conciliação entre os dois conceitos (a formação do homem natural e cidadão). Porém, ao contrário, considerando-se a sociedade legitima tal como projetada no Contrato Social, se os princípios pedagógicos forem estudados numa perspectiva de direito, não pode haver oposição entre as duas modalidades da educação do homem (Oliveira, 1977, p.92).

Outra ideia que identifica a unidade da obra rousseauniana pela educação consiste na ideia de liberdade que a perpassa, que é o fundamento sem o qual não se pode conceber o projeto de Rousseau. Como vimos no Emílio, há uma forte defesa da liberdade natural. Como Rousseau não pretende que o homem permaneça no estado de natureza sugere que ela seja preservada, no entanto é uma liberdade que ainda não eleva a condição humana. Com a educação, que visa à inserção social, Rousseau dá um grande avanço de cunho moral, ou seja, substitui-se a liberdade natural, 
desregrada pela liberdade moral. A grandeza da liberdade moral consiste em que, mesmo que o homem aja de acordo com as exigências do princípio da vontade geral, sua ação será sempre livre, pois tenderá sempre à realização do bem comum. Na verdade, Rousseau vai ser um dos grandes instigadores do debate sobre liberdade e ética, que não significa, de forma alguma, que o homem faça o que ele quer; ao contrário, só se fundamenta pela lei.

Disso resulta que a obra de Rousseau demonstra uma unidade de caráter pedagógico com a qual visa sempre à liberdade e à felicidade humana. Rousseau não faz apenas um discurso pedagógico. Como vimos, há em sua obra uma unidade fundamental que visa, em todos os seus princípios, ao desenvolvimento humano na República. Podemos, sim, agora afirmar, com convicção, que Emílio é preparado para viver em sociedade, não a sociedade apresentada em Os solitários, mas aquela sugerida pelo contrato que é regida por uma vontade geral como fundamento da ação humana.

A educação e a sociedade tiveram grandes avanços motivados a partir da leitura e do desafio do pensamento rousseauniano. Ele soube fazer síntese e propor inúmeras mudanças. O século dezenove descobriria a partir de Rousseau que é preciso amar as crianças. No ano em que comemoramos o aniversário da obra de Rousseau fica reforçado nesse estudo o papel de destaque que educação assume na cosmovisão rousseauniana. Sem dúvida alguma essa perspectiva inspirou muitos pensamentos e ações no contexto da modernidade. A educação atual é devedora de muitos reconhecimentos a esse pensador que com sua teoria serve ainda hoje de indicador de novas perspectivas de uma educação integral. Principalmente numa época em que a fragmentação e a superespecialização no torna míopes e segrega a formação do ser humana em diferentes fatias. Desse modo é valida a síntese

Filosofia e Educação - ISSN 1984-9605 - Volume 4, Número 2

Outubro de 2012 - Março de 2013 
de Rousseau entre homem natural e cidadão a partir de um olhar indissociável.

\section{Referências}

BOTO, Carlota. A escola do homem novo: entre o Iluminismo e a Revolução Francesa. São Paulo: Editora da Unesp, 1996. 207 p.

CERIZARA, Ana Beatriz. Rousseau: a educação na infância. Série pensamento e ação no magistério. São Paulo: Scipione, 1990. 176 p.

CHÂTEAU, Jean. Os grandes pedagogistas. São Paulo: Companhia Editora Nacional, 1978. 362 p.

HOBBES, Thomas. O Leviatã on matéria, forma e poder de um estado eclesiástico e civil. Os Pensadores. Trad. João Paulo Monteiro e Maria Beatriz Nizza da Silva. São Paulo: Abril cultural, 1974.423 p.

OLIVEIRA, Antônio Eunizé de. Jean Jacques Rousseau: pedagogia da liberdade. Joao Pessoa Ed. Universitária UFPb, 1977.100 p.

PEREIRA, Vilmar Alves. A Pedagogia de Rousseau: desafios da educaşão para século XVIII. 1. ed. PAsso Fundo: CLIO, 2002. v. 1. 120 p. - A defesa de uma pedagogia da natureza na obra Emílio ou da Educação de Rousseau. In: MARQUES, J. O. A. (org). (Org.). MARQUES, J. O. A. (org.) Verdades e mentiras: 30 ensaios em torno de Jean-Jacques Rousseau. Ijuí: Editora UNIJUÍ, 2005 (Coleção Filosofia) 520 p. Editora UNIJUÍ,: IjuiRS, 2005, v. 01, p. 433-451.

ROSSI, Wagner Gonçalves. Pedagogia do trabalbo: raízes da educação socialista. São Paulo: Moraes, 1981.192 p.

ROUSSEAU, Jean-Jacques. Ensaios. Cadernos da Universidade de Caxias do Sul. SULIANI, Antônio (org.). Caxias do Sul: Editora da UCS, 1979. 103 p. - Emílio ou da educação. Trad. Roberto Leal Ferreira. São Paulo: Martins

Fontes, 1995. (Paideia). 656 p.

Filosofia e Educação - ISSN 1984-9605 - Volume 4, Número 2

Outubro de 2012 - Março de 2013 
. O contrato social. Trad. Lourdes Machado. São Paulo: Abril Cultural, 1973. 431 p.

. Emile e Sophie ou os solitários. Trad. de Françoise Galler. Porto: Editora Paraula. Edição bilíngue, 1994. 247 p.

STAROBINSKI, Jean. Jean Jacques Rousseau: a transparência e o obstáculo. Trad. Maria Lúcia Machado. São Paulo: Companhia de Letras, 1981.560 p. 